\title{
Extracellular aspartic protease SAP2 of Candida albicans yeast cleaves human kininogens and releases proinflammatory peptides, Met-Lys-bradykinin and des-Arg ${ }^{9}-$ Met-Lys-bradykinin
}

\author{
Grazyna Bras' ${ }^{1}$, Oliwia Bochenska ${ }^{1}$, Maria Rapala- \\ Kozik $^{1}$, Ibeth Guevara-Lora ${ }^{1}$, Alexander Faussner ${ }^{2}$ \\ and Andrzej Kozik ${ }^{1} *$ \\ ${ }^{1}$ Faculty of Biochemistry, Biophysics and Biotechnology, \\ Jagiellonian University, Gronostajowa 7, 30-387 Krakow, \\ Poland \\ ${ }^{2}$ Institute for Cardiovascular Prevention, Ludwig \\ Maximilians University, Pettenkoferstrasse 8a/9, D-80336 \\ Munich, Germany \\ * Corresponding author \\ e-mail: andrzej.kozik@uj.edu.pl
}

\begin{abstract}
Bradykinin-related peptides, universal mediators of inflammation collectively referred to as the kinins, are often produced in excessive amounts during microbial infections. We have recently shown that the yeast Candida albicans, the major fungal pathogen to humans, can exploit two mechanisms to enhance kinin levels at the sites of candidial infection, one depending on adsorption and activation of the endogenous kinin-generating system of the host on the fungal cell wall and the other relying on cleavage of kinin precursors, the kininogens, by pathogen-secreted proteases. This work aimed at assigning this kininogenase activity to the major secreted aspartic protease of $C$. albicans (SAP2). The purified SAP2 was shown to cleave human kininogens, preferably the low molecular mass form (LK) and optimally in an acidic environment ( $\mathrm{pH} 3.5-4.0$ ), and to produce two kinins, Met-Lys-bradykinin and its derivative, [Hydroxyproline ${ }^{3}$ Met-Lys-bradykinin, both of which are capable of interacting with cellular bradykinin receptors of the B2 subtype. Additionally, albeit with a lower yield, des-Arg'-Met-Lysbradykinin, an effective agonist of B1-subtype receptors, was released. The pathophysiological potential of these kinins and des-Arg-kinin was also proven by presenting their ability to stimulate human promonocytic cells U937 to release proinflammatory interleukin $1 \beta$ (IL-1 $\beta$ ) and IL-6.
\end{abstract}

Keywords: Candida albicans; candidiasis; des-arginine ${ }^{10}$ kallidin; interleukins; kinin receptors; secreted aspartic proteases.

\section{Introduction}

Albeit common components of normal microflora on human skin and mucous membranes, unicellular fungi from the genus
Candida, predominantly Candida albicans, can cause severe diseases in individuals whose immune system has been weakened. These include patients with AIDS or those who have had surgery, organ transplantation and cancer therapy who are all particularly prone to life-threatening deep-seated mycoses of almost all inner organs, fungaemia or even systemic diseases, resulting in a high mortality rate (Odds et al., 2006). Candida albicans and other Candida species can also cause a range of persistent superficial infections of the gastrointestinal tract, oral cavity and vagina (Mavor et al., 2005). Owing to the gradually increasing incidence of various types of candidiasis over the last few decades, Candida yeasts are nowadays considered as the major fungal pathogens to humans (Karkowska-Kuleta et al., 2009).

The major virulence factors of these fungi include the transition from a yeast-like form to filamentous forms (Yang, 2003), the binding of host cells and proteins by fungal surface-exposed adhesins (Chaffin, 2008) and the secretion of a variety of hydrolytic enzymes (Schaller et al., 2005). Within the latter, the secreted aspartic proteases (SAPs) constitute one of the most effective tools used by the fungus to colonize and infect the host organism (Naglik et al., 2003a). SAPs play a dual role in candidial virulence, acting either non-specifically, digesting most of host proteins encountered to enable tissue colonization and to provide nutrients necessary for microbe proliferation (Morschhäuser et al., 1997), or more specifically, cleaving various regulatory proteins involved in the host defense. In particular, all the major systems for the biochemical homeostasis of the host, which are based on proteolytic cascades and include complement (Gropp et al., 2009), blood coagulation (Rüchel, 1983), fibrinolysis and kallikrein-kinin system (Kaminishi et al., 1990; Rapala-Kozik et al., 2010) can, by default, be dysregulated by the proteolytic enzymes released by the microbial pathogens into the host tissues and body fluids.

The kallikrein-kinin system generates bradykinin (BK)related peptides, collectively referred to as the kinins, which are potent vasoactive and proinflammatory mediators involved in the regulation of various physiologic and pathologic processes (Colman and Schmaier, 1997; Joseph and Kaplan, 2005). In the circulatory system, they cause vasodilatation, increased blood flow, increased vascular permeability and venoconstriction (Sharma, 2006). Involved in almost any kind of inflammation, the kinins induce a secondary release of pro-inflammatory mediators such as nitric oxide, prostaglandins and cytokines by a variety of effector cells (Blais et al., 2000; Moreau et al., 2005). The activation of the kininforming system has been suggested to constitute an important 
part of the human host defense against microbial infections (Oehmcke and Herwald, 2010). However, some kinin-exerted effects can be considered as 'beneficial' to pathogens, such as the enhancement of vascular permeability, which causes the inflow of plasma and facilitates the availability of nutrients and the spreading the pathogen within the host organism (Potempa and Pike, 2009).

The role of extracellular pathogen proteases has been well recognized in the kinin release associated with bacterial infections (Imamura et al., 2005; Rapala-Kozik et al., 2011; and references therein) but is unsatisfactorily characterized in candidiasis. Kaminishi et al. (1990) were the first to suggest a kinin-producing potential of the major $C$. albicans SAP, albeit indirect, based not on the simple cleavage of the proteinaceous kinin precursors, the kininogens, but rather on the activation of the endogenous kinin-forming cascade of the host. This fungal protease was shown to activate coagulation factor XII, which could then activate prekallikrein, the zymogen of plasma kallikrein, the dedicated kininogen-cleaving and BK-releasing protease. On the contrary, we recently found that a mixture of proteases released by $C$. albicans hyphae effectively cleaved human kininogens and released kinin peptides (Rapala-Kozik et al., 2010). The current work aimed to assign this kininogenase activity to SAP2, the major protease of $C$. albicans released to the medium under typical yeast culture conditions.

\section{Results}

Candida albicans possesses at least ten SAP genes, which are expressed at variable levels, depending on the specific culture conditions (White and Agabian, 1995) or on the infection phase in several in vitro models of candidial infection (Naglik et al., 2008). However, it is SAP2 that has been generally found to be produced in largest amounts in C. albicans cultures. In the present work, we used purified SAP2 to degrade human kininogens, determine the cleavage patterns, identify kinin-like peptides within the proteolysis products and prove their actual pathophysiologic, proinflammatory properties.

\section{Cleavage of human kininogens by purified C. albicans SAP2 led to the generation of kinin-like peptides}

A degradation of high molecular mass (HK) and low molecular mass (LK) forms of human kininogen by SAP2 was analyzed by sodium dodecyl sulfate polyacrylamide gel electrophoresis (SDS-PAGE). Electrophoretic patterns obtained from a representative time-course experiment are shown in Figure 1. In the SAP2-digested HK (Figure 1A), two fragments with molecular masses of approximately $65 \mathrm{kDa}$ and $55 \mathrm{kDa}$ were first formed, and later, on their expense, a $45 \mathrm{kDa}$ fragment appeared, which was relatively resistant to further degradation. The $65 \mathrm{kDa}$ and $45 \mathrm{kDa}$ bands had the electrophoretic mobility identical to those of heavy and light chains of plasma kallikrein-cleaved HK, respectively

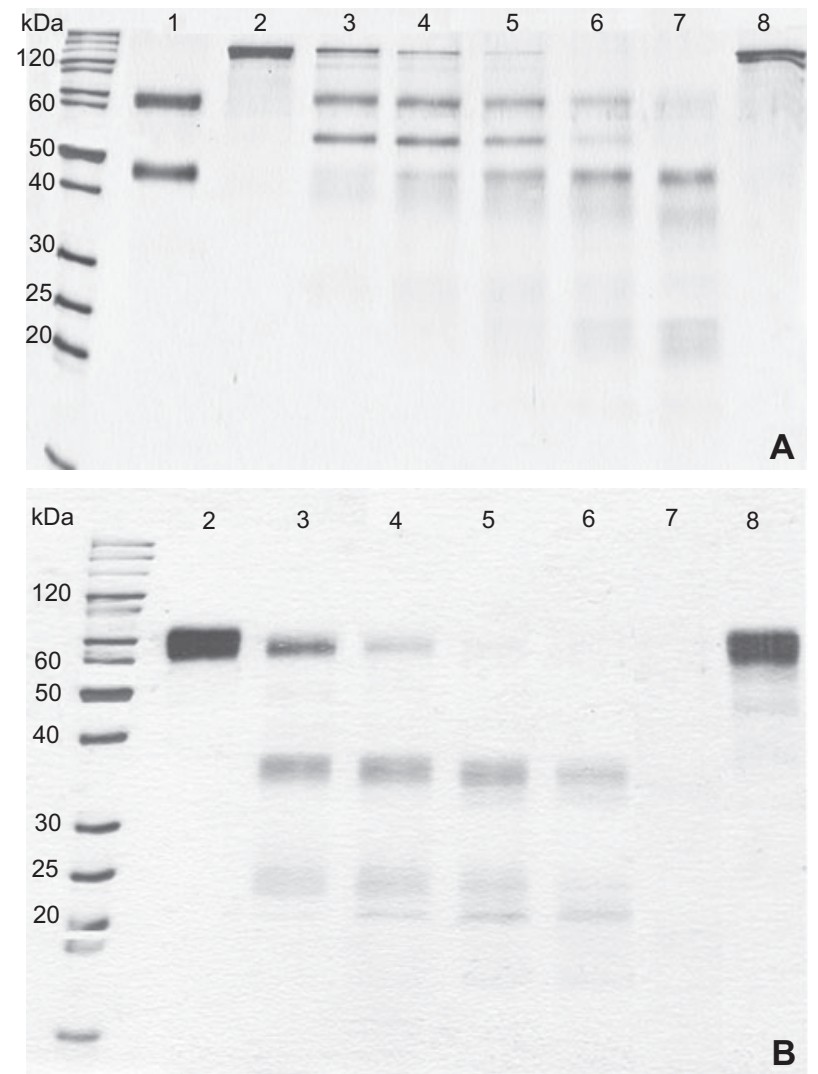

Figure 1 SDS-PAGE analysis of the degradation of human kininogens, HK (A) and LK (B), by SAP2.

Purified SAP2 was incubated with HK or LK at a 1:100 enzyme:substrate molar ratio in $50 \mathrm{~mm}$ citrate buffer $\mathrm{pH} 3.5$ at $37^{\circ} \mathrm{C}$ for $0 \mathrm{~min}$ (lane 2), $15 \mathrm{~min}$ (lane 3), $30 \mathrm{~min}$ (lane 4), $1 \mathrm{~h}$ (lane 5), $2 \mathrm{~h}$ (lane 6) and $5 \mathrm{~h}$ (lane 7). The digests were analyzed by SDS-PAGE in the Laemmli system (Laemmli, 1970) and the protein bands were visualized by silver staining. Lane 8 - the sample of HK or LK incubated without SAP2 under the same conditions; lane 1 - sample of plasma kallikrein cleaved HK.

(Figure 1A, lane 1). By contrast, LK was completely degraded to small SDS-PAGE undetectable peptides (Figure 1B), while faint bands at $35 \mathrm{kDa}$ and $20 \mathrm{kDa}$ were visible over the first $2 \mathrm{~h}$ of SAP2 digestion.

In an attempt to detect kinins in the SAP2-digested kininogen samples, an enzyme-linked immunosorbent assay (ELISA) method was first used that was specific for the last five amino acids of BK sequence. As shown in Figure 2, the kinins were indeed formed under SAP2 action on kininogens in both a concentration- and time-dependent manner (Figure $2 \mathrm{~A}$ and $2 \mathrm{~B}$, respectively). However, the yield of kinin formation from HK was an order of magnitude lower than that from LK.

For LK, as the better substrate for SAP2, we also analyzed the $\mathrm{pH}$ dependence of kinin release by this protease (Figure 3). The kinin production was highest at $\mathrm{pH} 3.5$ and gradually decreased with $\mathrm{pH}$ increase until $\mathrm{pH} 6.0$, after which kinins could barely be detected. 

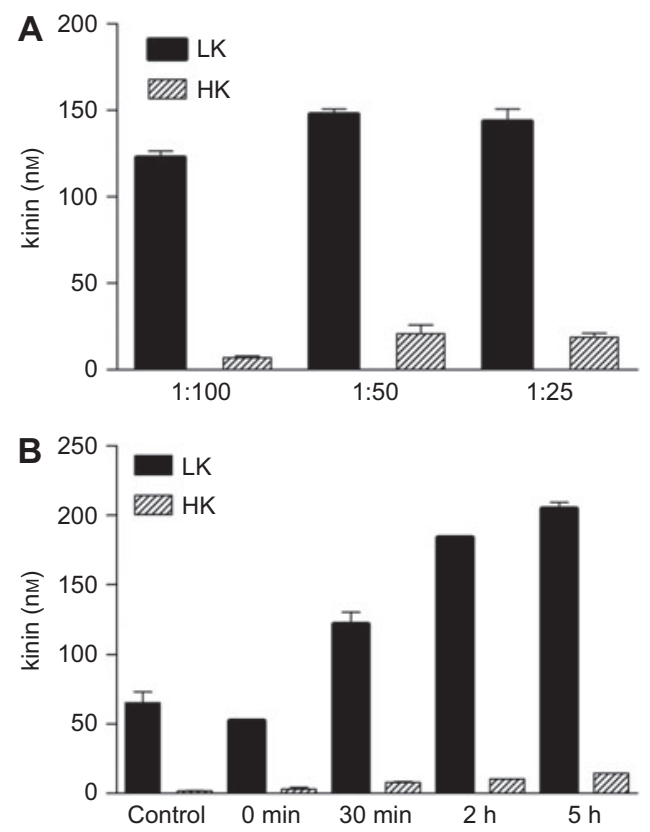

Figure 2 Production of kinin peptides from human kininogens by SAP2.

HK $(1 \mu \mathrm{M})$ and LK $(1.5 \mu \mathrm{M})$ in $50 \mathrm{~mm}$ citrate buffer $\mathrm{pH} 3.5$ were incubated at $37^{\circ} \mathrm{C}$ with purified SAP2 at variable concentration for $5 \mathrm{~h}$ (A) or at fixed concentration (1:50 enzyme:substrate molar ratio) for variable time (B). The reaction was stopped with $10 \mu \mathrm{M}$ pepstatin A. The kinin content in the samples was determined with a BK-dedicated ELISA kit.

\section{Met-Lys-BK and des-Arg ${ }^{9}-M e t-L y s-B K$ were identified in the peptide mixture generated from kininogens by SAP2}

In an attempt to identify the chemical nature of kinins produced by SAP2 from kininogens and to determine the mechanism of kininogen cleavage, we first analyzed the SAP2-catalyzed fragmentation of a synthetic 26-amino acid peptide (HK358-383) with the sequence ISLMKRPPGFSPFRSSRIGEIKEETT matching that of

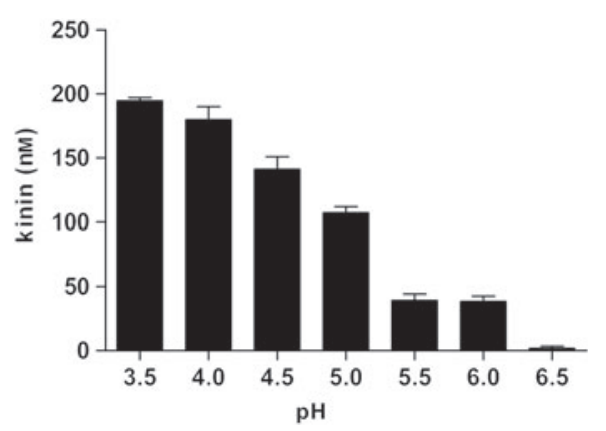

Figure 3 Dependence of kinin release from LK by SAP2 on $\mathrm{pH}$. LK $(1 \mu \mathrm{M})$ was incubated at $37^{\circ} \mathrm{C}$ with purified SAP2 $(20 \mathrm{nM})$ in 50 mM citrate buffer $\mathrm{pH} 3.5-5.5$ or $50 \mathrm{~mm}$ phosphate buffer $\mathrm{pH}$ 5.5-6.5. After $5 \mathrm{~h}$, the reaction was stopped with pepstatin A and the kinin concentration was determined by ELISA. the kinin-containing domain D4 of human kininogens. Multiple cleavage products formed and were separated by high-performance liquid chromatography (HPLC) and identified by electrospray-ionization mass spectrometry (ESI-MS). In Figure 4, the time course of a representative HK358-383 fragmentation is presented in terms of chromatographic peak areas. Owing to highly preferable cleavage of peptide bonds after L360 and K379 or G376 (numbering according to the natural kininogen sequence), two major products, MKRPPGFSPFRSSRIGEIK (1) and MKRPPGFSPFRSSRIG (2) were formed within first 15-30 min and quickly disappeared, giving rise to further products. These were produced exclusively owing to the cleavages downstream from the kinin sequence and included MKRPPGFSPFRSS (4), MKRPPGFSPFRSSR (3), MKRPPGFSPFRS (5) and MKRPPGFSPFR (6), and were probably formed simultaneously but at rates decreasing in that order. The latter peptide is a true kinin, $\mathrm{Met}^{-1}-\mathrm{Lys}^{0}$-BK (Met ${ }^{0}$-kallidin, MKD). The amounts of peptides 4 and 5 slowly decreased on the time scale of hours, suggesting their further conversion, mainly to MKRPPGFSPF (7) and MKRPPGFS (8). The abundance of the two latter peptides, after passing a lag phase, progressively increased toward the end of the experiment. Peptide 7 is a potentially biologically
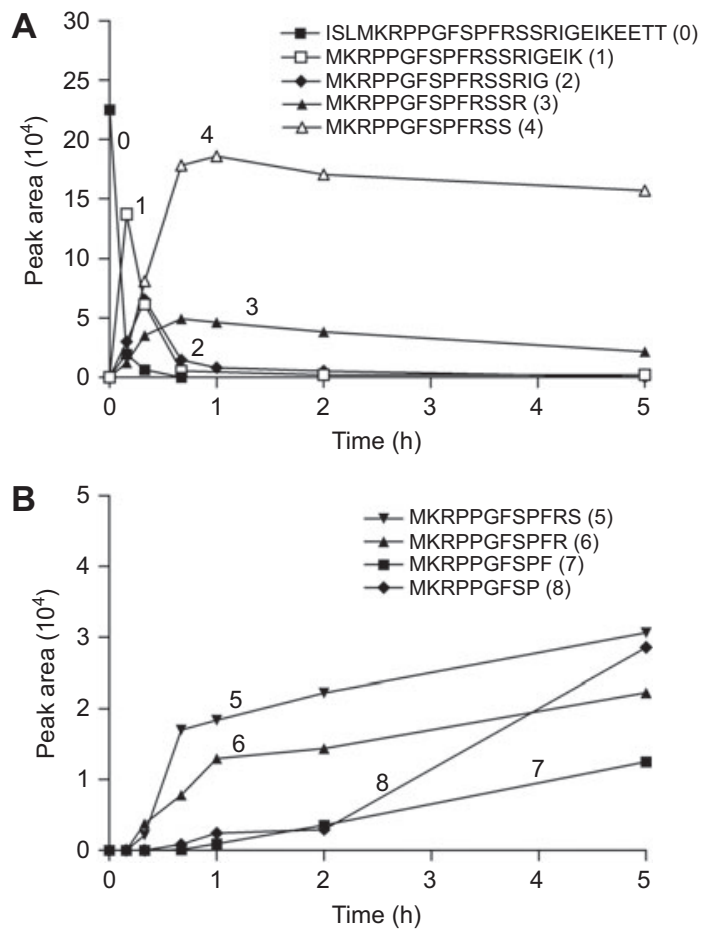

Figure 4 HPLC/MS analysis of the hydrolysis of synthetic peptide HK358-383 by SAP2.

SAP2 was incubated with $10 \mu \mathrm{M}$ HK358-383 peptide in $50 \mathrm{~mm}$ citrate buffer $\mathrm{pH} 3.5$ at $37^{\circ} \mathrm{C}$ at a 1:50 enzyme:substrate molar ratio. At specified time, the reaction was stopped with pepstatin A. The peptides formed were separated by reversed-phase HPLC and identified by ESI-MS. The time-course in terms of peak areas are shown for the major products formed in the early phase (A) and less abundant products which increased toward the end of the experiment (B). 
active kinin metabolite, des-Arg ${ }^{9}-\mathrm{Met}^{-1}{ }^{-} \mathrm{Lys}^{0}$-BK (des-Arg ${ }^{10}$ Met $^{0}$-kallidin, des-Arg-MKD). It was unlikely to have been formed from MKD (peptide 6), as in separate experiments we showed that this kinin was completely resistant to SAP2 (endopeptidase) action (data not shown). It should also be emphasized that, apart from peptides 7 and 8 , all earlier products of SAP2-catalyzed fragmentation of HK358-383 contained the intact kinin sequence.

The above predictions from the SAP2-mediated cleavage of the synthetic peptide, mimicking the domain D4, were verified using native kininogens as SAP2 substrates. The chromatograms of samples obtained after extensive digestion of HK and LK by SAP2 are shown in Figure 5. While no peptides with the same retention times as the standards of the major kinins, i.e., BK and kallidin (Lys-BK, KD), could be detected, minor peaks with the retention time corresponding to that of MKD were visible, especially in the LK digest (Figure 5B). The peptide fractions were collected and analyzed for kinin content by ELISA. Two ELISA-positive fractions were found (Figure 5), one major at the same retention time as that of MKD and another, smaller, slightly shifted to a shorter retention time relatively to BK standard.

The peptide fractions from the HPLC separation of LK, digested with SAP2, were also analyzed by ESI-MS to identify the major products formed and eluted within the 'kinin retention time window' (32-46 min). A list of identified peptides are presented in Table 1, and the mass spectra of two fractions that gave positive reading on ELISA tests for kinins (see above) are shown in Figure 6.

The major fraction of ELISA-detectable kinin, eluted at 38 min, was proven to be relatively pure MKD. The second kinin-positive fraction with the shorter elution time of $36 \mathrm{~min}$ contained two peptides with estimated molecular masses of 1492.8 Da and 1334.7 Da. The latter differed in mass from MKD by $16 \mathrm{Da}$ and was finally identified by MS-MS, i.e., with the analysis of parental ion fragmentation in the mass spectrometer, to have hydroxyproline (Hyp) in the fifth position of its sequence, otherwise identical to that of MKD. This compound gave a BK-equivalent response in the ELISA test used in this work. Albeit barely visible on chromatograms and undetectable on ELISA, des-Arg-MKD (eluted at $\sim 44 \mathrm{~min}$ ) was also identified as a very minor product of LK fragmentation by SAP2 (Table 1).
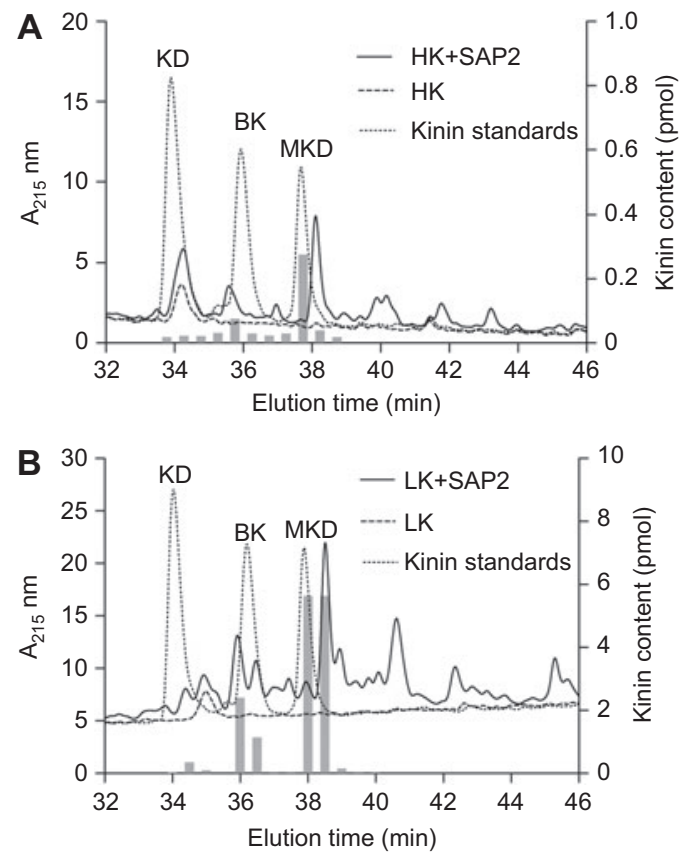

Figure 5 HPLC/ELISA analysis of kinins released from human kininogens by SAP2.

$1 \mu \mathrm{M} \mathrm{HK}$ (A) and $1.5 \mu \mathrm{M} \mathrm{LK}$ (B) were incubated in $50 \mathrm{~mm}$ citrate buffer $\mathrm{pH} 3.5$ with purified SAP2 at $37^{\circ} \mathrm{C}$ for $5 \mathrm{~h}$. The obtained peptide mixture were separated by HPLC and the eluted fractions $(0.5 \mathrm{ml})$ were collected, evaporated and analyzed for kinin content by ELISA (bars). Chromatograms of the kininogens, incubated for $5 \mathrm{~h}$ in the buffer without SAP2 (dashed line) and of the kinin mixture (dotted line) containing $\mathrm{KD}, \mathrm{BK}$ and $\mathrm{MKD}$ are superimposed on the chromatograms of the digested kininogens (solid line).

\section{Met-Lys-BK and des-Arg'-Met-Lys-BK, generated from kininogens by SAP2, interacted with cellular kinin receptors}

Independently from the chemical identification of the kininlike products of kininogen fragmentation by SAP2, the mixtures of SAP2-generated kininogen fragments were tested for interaction with the two known subtypes of kinin receptors, RB1 and RB2, specific for des-Arg-kinins and normal-length kinins, respectively. For that purpose, a radioreceptor assay was used, based on a competition of kinin-like peptides with

Table 1 ESI-MS identification of the peptides generated from LK by SAP2.

\begin{tabular}{llcl}
\hline Elution time $(\mathrm{min})$ & \multicolumn{1}{c}{$\mathrm{m} / \mathrm{z}$} & $\begin{array}{c}\text { Molecular mass from } \\
\text { mass spectra (Da) }\end{array}$ & Peptide amino acid sequence \\
\hline $34-34.5$ & $504.0(+3), 755.4(+2)$ & 1508.8 & MKRPP(OH)GFSPFRSS \\
$34.5-35,35-35.5$ & $413.2(+4), 550.6(+3), 825(+2)$ & 1648.8 & MKRPPGFSPFRSSR \\
$36-36.5$ & $498.6(+3), 747.9(+2)$ & 1492.8 & MKRPPGFSPFRSS \\
& $\mathbf{4 4 5 . 9 ( + 3 ) , 6 6 8 . 4 ( + 2 )}$ & $\mathbf{1 3 3 4 . 7}$ & MKRPP(OH)GFSPFR \\
$36.5-37$ & $498.6(+3), 747.4(+2)$ & 1492.8 & MKRPPGFSPFRS \\
$37-37.5$ & $469.6(+3), 703.9(+2)$ & 1405.9 & MKRPPGFSPFRS \\
$38-38.5,38.5-39$ & $\mathbf{4 4 0 . 6 ( + 3 ) , 6 6 0 . 4 ( + 2 )}$ & $\mathbf{1 3 1 8 . 7}$ & MKRPPGFSPFR \\
$40.5-41$ & $456.0(+4), 607.4(+3)$ & 1819.1 & MKRPPGFSPFRSSRIG \\
$44-44.5$ & $\mathbf{5 8 2 . 3}(+\mathbf{2})$ & $\mathbf{1 1 6 2 . 6}$ & MKRPPGFSPF \\
\hline
\end{tabular}

The identified kinins and des-Arg-kinin are marked with bold font. 

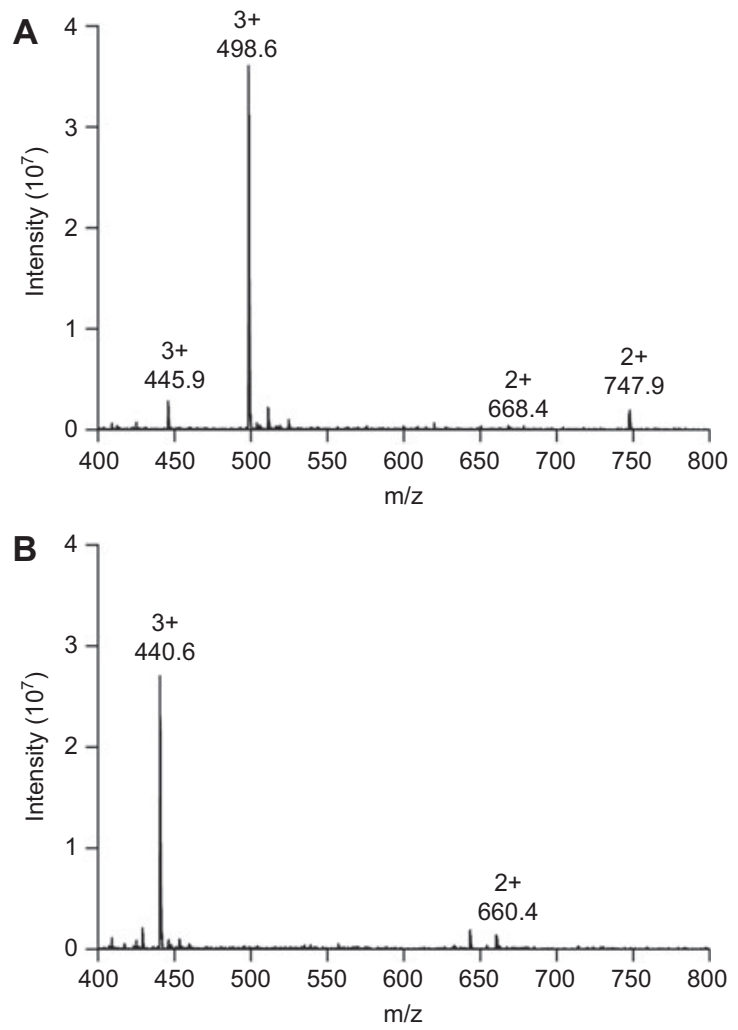

Figure 6 ESI-MS spectra of kinins generated from LK by SAP2.

Fractions after HPLC separation of LK digests (Figure 5B), with elution time of 36-36.5 $\mathrm{min}$ (A) and 38-38.5 (B) were evaporated to dryness, dissolved in $30 \%$ methanol with $0.1 \% \mathrm{HCOOH}$ and analyzed with an ESI-ion trap mass spectrometer.

tritium-labeled BK for binding to HEK 293 cells that stably overexpress RB2 or with tritium-labeled des-Arg ${ }^{10}$-kallidin (DAKD) for binding to HEK 293 with overexpressed RB1. The SAP2-generated digests of LK were found to interact with both of these two subtypes of kinin receptors (Figure 7), though much more strongly with RB2.

These receptor-binding activities in the crude SAP2-digest of LK were further assigned to the fractions collected upon its separation by HPLC, such as that presented in Figure 5B. The RB2-binding peptides were found in the fractions eluted at 35.5-36 and 37.5-38.5 min (Figure 8A), the same that showed the presence of ordinary kinins on ELISA tests and, as evidenced by mass spectrometric analysis, contained [ $\left.\mathrm{Hyp}^{4}\right]-$ MKD and MKD, respectively. The RB1-binding activity was solely assigned to the fraction eluted at 44-45.5 min (Figure 8B), in which des-Arg-MKD was identified.

Finally, using the samples of pure, chemically synthesized MKD and des-Arg-MKD, we compared their affinities to kinin receptors with those of more typical kinins and desArg-kinins. The sets of corresponding displacement plots are shown in Figure 9. While des-Arg-MKD was found to be equivalent to DAKD, generally considered as the best agonist of human RB1, MKD had a lower, by an order of magnitude, affinity to RB2 as compared with that of BK or KD.

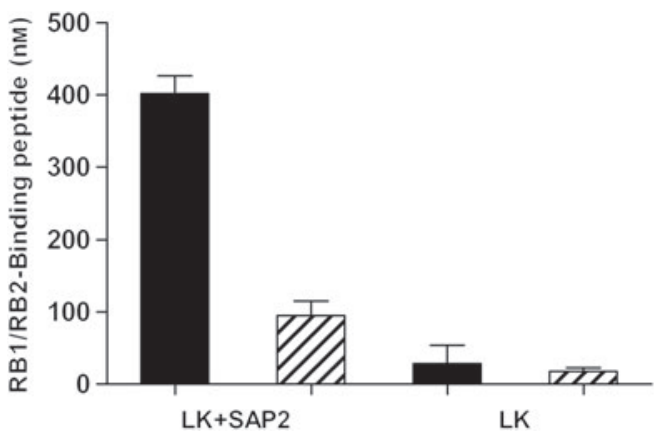

Figure 7 Cellular kinin receptor-binding assay of peptides produced from LK by SAP2.

Monolayers of HEK 293 cells with over-expressed RB2 (solid bars) or RB1 (dashed bars) were incubated at $4^{\circ} \mathrm{C}$ with mixtures of a diluted sample of SAP2-digested LK (at 1:50 molar ratio) and $2 \mathrm{~nm}\left[{ }^{3} \mathrm{H}\right]-\mathrm{BK}$ or $1 \mathrm{nM}\left[{ }^{3} \mathrm{H}\right]-\mathrm{DAKD}$, respectively. As a control, native undigested LK incubated for $5 \mathrm{~h}$ in $50 \mathrm{~mm}$ citrate buffer $\mathrm{pH} 3.5$ at $37^{\circ} \mathrm{C}$, was used. After washing, the cell surface-bound $\left[{ }^{3} \mathrm{H}\right]-\mathrm{BK}$ or $\left[{ }^{3} \mathrm{H}\right]$-DAKD were dissociated by acetic acid/ $\mathrm{NaCl}$ treatment and the released radioactivity was measured in a beta-counter. The amounts of kinin-like peptides in the samples were estimated from calibration plots, prepared with MKD or des- $\operatorname{Arg}^{10}-\mathrm{MKD}$, respectively (see Figure 9).
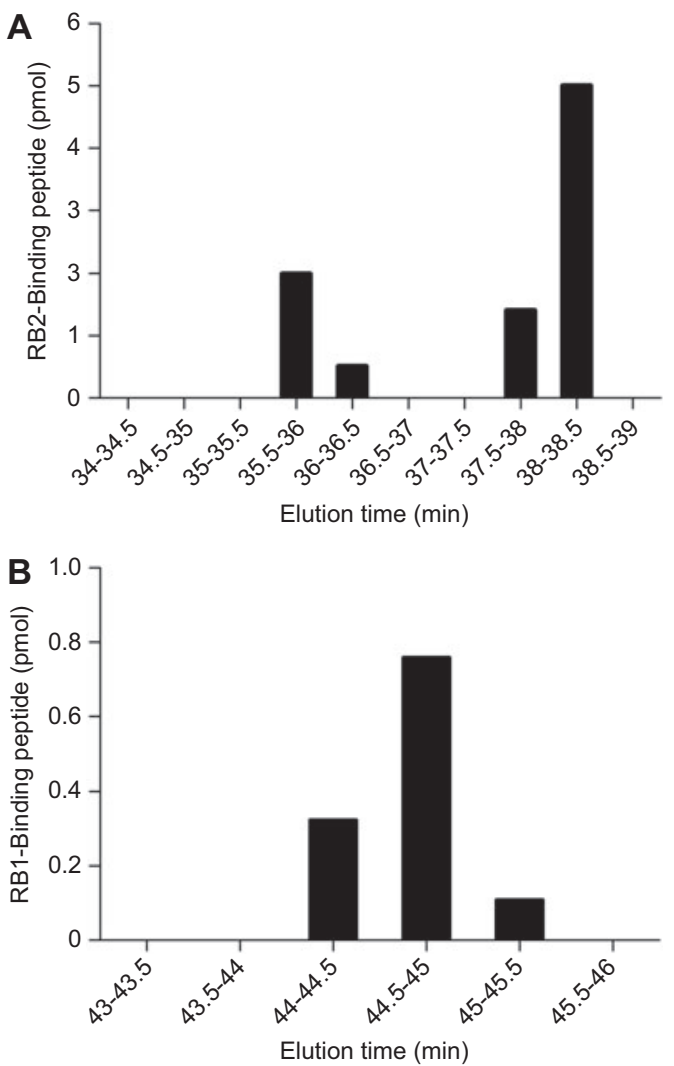

Figure 8 Cellular kinin receptor-binding assay of HPLC-separated peptides produced from LK by SAP2.

Collected and evaporated half-minute fractions after HPLC separation (see Figure 5B) of the LK sample, treated with SAP2 at 50:1 molar ratio were analyzed by competitive radioreceptor-assay with RB2-expressing (A) or RB1-expressing (B) HEK 293 cells and $\left[{ }^{3} \mathrm{H}\right]-\mathrm{BK}$ or $\left[{ }^{3} \mathrm{H}\right]-\mathrm{DAKD}$ as radioactive tracers, respectively (as described under the Figure 7). 

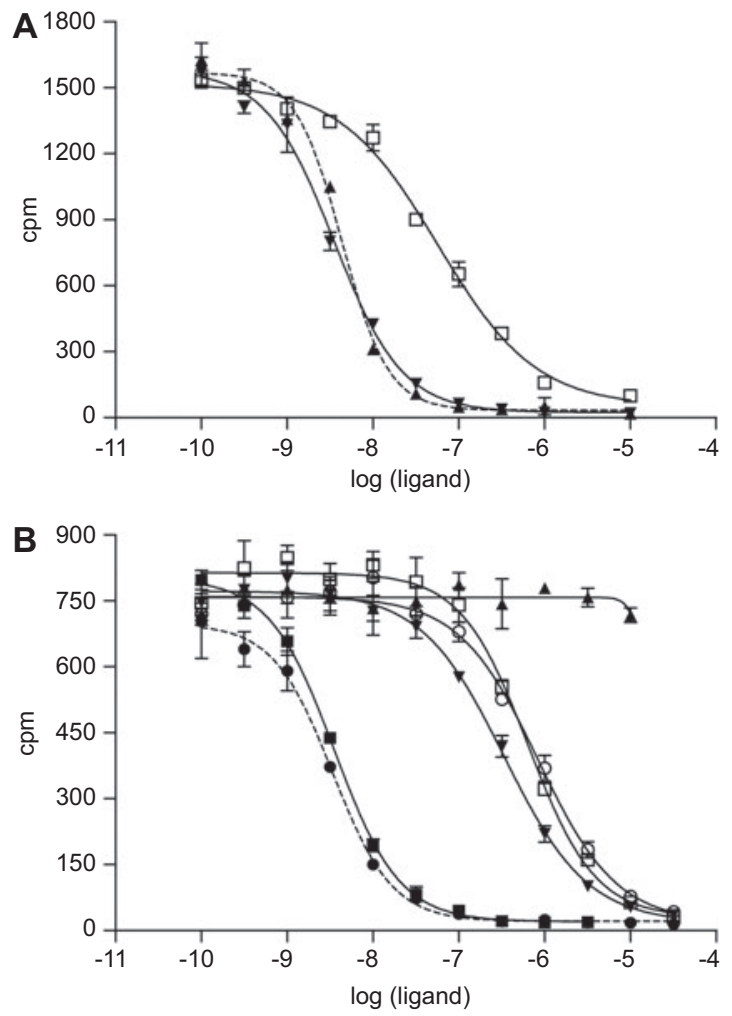

Figure 9 Plots of the displacement of $\left[{ }^{3} \mathrm{H}\right]-\mathrm{BK}$ from RB2expressing HEK 293 cells (A) or $\left[{ }^{3} \mathrm{H}\right]$-DAKD from RB1-expressing HEK 293 cells (B) by full length kinins and des-Arg-kinins.

Calibration plots for the cellular kinin receptor-binding assay performed as described under Figure 7 but with solutions (15 pM to 50 $\mu \mathrm{M})$ of pure kinins: BK $(\mathbf{\Delta}), \mathrm{KD}(\boldsymbol{\nabla})$ and MKD bradykinin $(\square)$ as well as pure des-Arg-kinins: des-Arg ${ }^{9}-\mathrm{BK}(\mathrm{O}), \operatorname{des}^{-\operatorname{Arg}^{10}-\mathrm{KD}}(\bullet)$ and des-Arg ${ }^{10}$-MKD (匹).

\section{Met-Lys-BK stimulated human promonocytic U937 cells to secrete proinflammatory interleukins}

A typical biological effect of kinins, the stimulation of various cells to release other proinflammatory mediators, was also determined for the kinin MKD generated by SAP2 from kininogens. The U937 cell line was used as a cellular model and the secretion of two proinflammatory interleukins (ILs), IL-1 $\beta$ and IL-6, under the influence of lipopolysaccharide (LPS), kinin standards or the samples of SAP2-digested LK was analyzed with specific ELISA kits (Figure 10). It was found that $1 \mathrm{~nm} \mathrm{MKD}$, similarly to $\mathrm{BK}$, could trigger these inflammatory pathways (Figure 10A) and that, with the increasing concentration of MKD in the cell suspension, the concentration of the cell-secreted IL-1 $\beta$ and IL-6 also increased (Figure 10B).

\section{Discussion}

The basic mechanisms underlying the activation of the kallikrein-kinin system during bacterial infections (Imamura
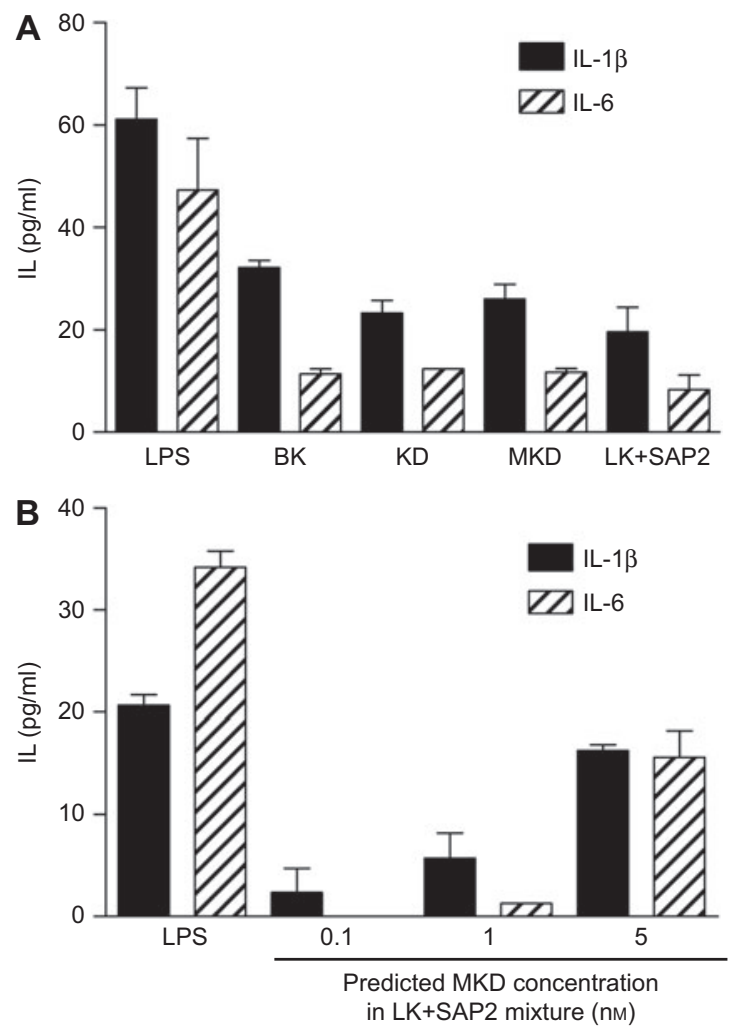

Figure 10 Secretion of IL-1 $\beta$ and IL-6 by human promonocytic U937 cells under the influence of MKD, released from LK by SAP2.

Undifferentiated U937 cells $\left(4 \times 10^{6}\right.$ cells) were incubated for $24 \mathrm{~h}$ in $250 \mu \mathrm{l}$ RPMI 1640 medium with $2 \%$ FBS supplemented with $100 \mathrm{ng} / \mathrm{ml}$ LPS (positive control), $1 \mathrm{~nm}$ kinin standards of BK, KD, MKD (A), SAP-2-degraded LK predicted to contain 1 nM MKD (A) or diluted samples of the last one, predicted to contain 0.1-5 nM MKD (B). Samples of SAP2 served as negative control, and the readings from those control samples were subtracted from the results obtained for other test samples. The concentration of IL-1 $\beta$ (solid bars) and IL-6 (dashed bars) in the supernatants from above the cells were determined by specific ELISA tests.

et al., 2004) have recently been suggested to contribute also to the virulence of Candida yeasts, the major fungal pathogens to humans. The first one involves the assembly of components of the endogenous kinin-forming system of the host on the pathogen surfaces, including the primarily adsorbed kininogens (kinin precursors) and kallikreins as the final kinin-releasing proteases (Rapala-Kozik et al., 2008; Karkowska-Kuleta et al., 2010, 2011). The other pathway engages extracellular proteases of the pathogen to activate the upstream-acting zymogens of the host kinin-generating cascade (Kaminishi et al., 1990) or to cleave the kininogens directly (Rapala-Kozik et al., 2010). The latter mechanism was reported for the mixture of proteases released by filamentous forms of $C$. albicans and several other Candida species. However, it was not determined which of the ten different SAPs produced by $C$. albicans could be assigned this kininogenase activity. 
In this work, we showed that it was SAP2 that reproduced most of the kinin-releasing characteristics previously determined for the unfractionated SAP mixture. We also identified the kinins formed and confirmed their actual biological (proinflammatory) activity.

Our study revealed striking differences between the two forms of human kininogen in their susceptibility to SAP2catalyzed processing (Figures 1 and 2). LK was quickly degraded to a mixture of small peptides, containing kinins in a reasonable yield of approximately $10 \%$ of kininogen molecules 'productively' processed toward the kinin release. On the contrary, HK was first split into big fragments, with molecular masses corresponding to those of heavy and light chains normally generated from HK by kallikreins. The heavy chain, which is the same as in LK, was then degraded, but the HK light chain seemed to persist for a relatively long time. This observation can be relevant to numerous recent reports of unique functions of this part of the HK molecule (Lalmanachetal., 2010), particularly of its cell surface-binding domain D5, sometimes referred to as the 'kininostatin' (Colman et al., 2000). These functions, apparently masked in the full-length kinin-containing HK, include, but are not limited to, specific proinflammatory cellular signaling (Khan et al., 2006), different from that triggered by the interaction of kinins with their cellular receptors (Leeb-Lundberg et al., 2005). Consistent with that hypothesis, the yield of kinin production from HK was an order of magnitude lower than that from LK, additionally suggesting some shielding of the kinin-containing domain D4 by the light chain against SAP2 action. According to a generally accepted model, the two forms of human kininogens play different roles at local inflammatory foci, LK being the preferable substrate for kinin production in the fluid phase by tissue kallikrein (Joseph and Kaplan, 2005) and HK being a substrate for the cell surface-localized kinin release, primarily by plasma kallikrein (Reddigari et al., 1995; Barbasz et al., 2008; Barbasz and Kozik, 2009). In the context of candidiasis, our present findings suggest that the two mechanisms of the fungal infection-associated upregulation of kinin-forming systems, i.e., the pathogen cell wall-dependent contact system activation vs. the release of kinins from kininogens by SAPs, have distinct significances.

The SAP2-catalyzed cleavage of the synthetic peptide, mimicking the kininogen domain D4 (HK358-383) produced several major peptides that contained the internal kinin sequence intact (Figure 4) and, hence, could still potentially be the sources of kinins in vivo under actions of other proteases, from either the pathogen or the host. However, slower minor cleavages in the presence of SAP2 led to the formation of a small amount of a true kinin, MKD, together with traces of des-Arg ${ }^{10}$-MKD and des-Arg ${ }^{10}$-des-Phe ${ }^{9}$-MKD. MKD was also identified in the SAP2-generated digests of kininogens (Figures 5 and 6). Additionally, [Hyp $\left.{ }^{4}\right]-\mathrm{MKD}$ was found, obviously owing to the post-translational modification of kininogens, which happens with approximately $30 \%$ frequency in the human population and results in an occurrence of hydroxyproline in the third position of BK sequence (Sasaguri et al., 1988).
The kininogen digests, obtained by SAP2 action, were also shown to possess biological activities characteristic of kinins and des-Arg-kinins. The mixture of SAP2-generated fragments of LK was found to interact with HEK 293 cells engineered to overexpress kinin receptors on their cell membrane (Figure 7). The tests for RB2-binding, performed on peptide fractions obtained from the HPLC separation of SAP2-digested LK, unequivocally assigned this activity to fractions shown to contain MKD and [ $\left.\mathrm{Hyp}^{4}\right]-\mathrm{MKD}$ (Figure 8). Conversely, RB1-binding was solely found in the fraction, in which des-Arg-MKD was detected.

MKD is a rather rare kinin, confirmed, for example, to occur in human urine (Hial et al., 1976) and to be formed from kininogens by human renal acid proteinase (Gomes et al., 1997), from LK by a mixture of elastase and plasma kallikrein (Sato and Nagasawa, 1988) or from HK by a combination of the neutrophil proteinase- 3 and angiotensin converting enzyme (Gera et al., 2011). Albeit assumed to have proinflammatory properties comparable to those of BK and $\mathrm{KD}$, this peptide has not been satisfactorily characterized as an agonist of kinin receptors. In this work, using pure, synthetic MKD, we found that its affinity to RB2 receptors was an order of magnitude lower than those of the two major kinins, BK and KD (Figure 9A). This finding does not necessarily mean that the overall biological activity of this kinin in vivo is insufficient, as numerous aminopeptidases known to be abundantly present in body fluids and at the inflammation sites (Moreau et al., 2005) can remove the N-terminal methionyl residue from this peptide and thus upgrade it to highly efficient RB2 agonists. On the contrary, des-ArgMKD was found to be equivalent to DAKD (Figure 9B), the best agonist of human $\mathrm{RB} 1$, the receptor known to be involved in chronic inflammation.

In this work, we also preliminarily tested the kinin and desArg-kinin, released from kininogens by SAP2, for another biological activity typical of this group of bioactive peptides, namely the ability to induce the release of secondary proinflammatory mediators by a variety of cells involved in the propagation of inflammatory state (Sainz et al., 2007). We showed that the SAP2-generated digest of LK stimulated the human U937 promonocyte cells to secrete two proinflammatory ILs, IL-1 $\beta$ and IL-6 (Figure 10) and that the pure synthetic MKD had an IL-releasing activity equivalent to those of BK and KD. The same equivalence was observed between corresponding des-Arg-kinins. Preliminary tests showed that the IL production was significantly quenched in the presence of kinin receptor antagonists such as HOE140 (results not presented).

The current study of the action of purified SAP2 on human kininogens reproduced all characteristics previously determined for the kininogen cleavage by the mixture of proteases released by C. albicans hyphae (Rapala-Kozik et al., 2010), except the increase of kinin production toward neutral $\mathrm{pH}$. This suggests that at a higher $\mathrm{pH}$, when the activity of SAP2 is reduced, other proteinases take over its role. These may include other $C$. albicans SAPs with more neutral $\mathrm{pH}$ optima, such as the SAP4-6 subset (Naglik et al., 2003a), or serineor metalloproteinases that occasionally have been reported to 
occur in this yeast species (Rodier et al., 1999; dos Santos et al., 2006).

Nevertheless, the current study strongly suggests that SAP2 can play the kinin-releasing role in some infections in niches of low $\mathrm{pH}$ such as stomach, vagina or urinary tract and/or where this protease dominates over the other SAPs. Unfortunately, reports on the relative expression levels of the ten SAPs of $C$. albicans present contradictory pictures, depending on the infection model applied (Naglik et al., 1999, 2003b; Taylor et al., 2005). However, in general, the expression of SAP2 was usually high and stayed relatively constant during the infection progress (Naglik et al., 2008).

\section{Conclusions}

In this work, purified SAP2, the major secreted protease of C. albicans, was shown to cleave human kininogens, with a high preference to LK as substrate. The mixture of SAP2generated kininogen fragments contained MKD and its derivative with a hydroxyproline residue at the forth position, both being potent agonists of cellular BK receptors of subtype B2, involved in immediate inflammatory reactions. Small amounts of des- $\mathrm{Arg}^{10}$-MKD were also detected and found to be excellent agonists of BK B1-subtype receptors, which are induced and involved in chronic inflammations. The SAP2-cleaved kininogen was also shown to stimulate human promonocyte U937 cells to release proinflammatory ILs IL-1 $\beta$ and Il-6. Because SAP2 is abundantly secreted by yeast in the culture and some infection models, our results suggest a major role for it in kinin release during candidiasis.

\section{Materials and methods}

\section{Yeast strain and yeast culture media}

The $C$. albicans ATCC 10231 strain from the American Type Culture Collection (Manassas, VA, USA) was grown on YPD medium (2\% glucose, $1 \%$ peptone, $0.5 \%$ yeast extract), obtained from Sigma (St. Louis, $\mathrm{MO}$, USA), at $30^{\circ} \mathrm{C}$ overnight in a rotary shaker. Citrate buffered (15 mM, pH 4.0) YCB (1.2\%) medium (Sigma), supplemented with $0.2 \%$ bovine serum albumin (BSA, Sigma) was used for SAP2 induction.

\section{SAP2 production and purification}

SAP2 was obtained from the $C$. albicans culture supernatant. About $2 \times 10^{8}$ yeast cells grown in YPD medium to late logarithmic phase were inoculated to 11 of $1.2 \%$ YCB medium containing $0.2 \% \mathrm{BSA}$ and grown for $72 \mathrm{~h}$ at $30^{\circ} \mathrm{C}$. The culture was centrifuged $(3000 \mathrm{~g}$, $15 \mathrm{~min}, 4^{\circ} \mathrm{C}$ ) and the supernatant was concentrated approximately 100-fold in an Amicon ultrafiltration chamber with Ultracel YM membrane (10 kDa molecular mass cut-off, Millipore, Billerica, MA, USA). The SAP2 purification was performed by ion exchange chromatographic methods adapted from Smolenski et al. (1997). The concentrated supernatant was dialyzed against $20 \mathrm{~mm}$ Tris- $\mathrm{HCl}$ buffer $\mathrm{pH} 6.5$ and applied to a pre-equilibrated Resource ${ }^{\mathrm{TM}} \mathrm{Q}$ (GE Healthcare/Pharmacia, Uppsala, Sweden) $1 \mathrm{ml}$ column and eluted with $30 \mathrm{ml}$ linear gradient from $20 \mathrm{~mm}$ Tris- $\mathrm{HCl} \mathrm{pH} 6.5$ to the same buffer with $0.5 \mathrm{M}$ sodium chloride $(\mathrm{NaCl})$, at a flow rate of $1 \mathrm{ml} / \mathrm{min}$ and with spectrophotometric detection at $280 \mathrm{~nm}$. Fractions with detectable proteolytic activity (see below) were pooled and dialyzed against $20 \mathrm{~mm}$ Tris- $\mathrm{HCl}$ buffer $\mathrm{pH}$ 6.5. The SAP2-containing sample was then applied to a pre-equilibrated Pharmacia Mono Q HR 5/5 column and eluted with $20 \mathrm{ml}$ linear gradient to $0.3 \mathrm{M} \mathrm{NaCl}$ in the same Tris buffer at a flow rate of $1 \mathrm{ml} / \mathrm{min}$ and with spectrophotometric detection at $280 \mathrm{~nm}$. The pooled active fractions were analyzed for protein content by the BCA method (Smith et al., 1985), using BSA as a standard. The purified protein passed homogeneity tests by SDS-PAGE in the Laemmli system (Laemmli, 1970), using reducing sample buffer, $12 \%$ gel and band visualization by silver staining. The purified SAP2 was stored frozen at $-20^{\circ} \mathrm{C}$.

During the preparation, the proteolytic activity was determined against azocasein as a substrate (modified after Morrow et al., 1992). A $30 \mu \mathrm{l}$ volume of concentrated supernatant/fraction was incubated with $100 \mu \mathrm{l}$ of $1 \%$ azocasein (Sigma) in $50 \mathrm{~mm}$ citrate buffer $\mathrm{pH}$ 3.5 at $37^{\circ} \mathrm{C}$ for $3 \mathrm{~h}$. After incubation, the undigested substrate was precipitated with $15 \%$ trichloroacetic acid (TCA) and removed by centrifugation (10 $000 \mathrm{~g}, 5 \mathrm{~min})$. The supernatant was then neutralized with $1 \mathrm{M} \mathrm{NaOH}$ and the concentration of the soluble products of the proteolytic reaction was determined by absorbance measurements at $440 \mathrm{~nm}$ in a Power WaveX-Select microplate reader (BioTek Instruments, Winoosky, VT, USA).

The identity of SAP2 was confirmed by trypsin digestion followed by LC/MS/MS analysis and database search. The purified protein $(10 \mu \mathrm{g})$ was suspended in $50 \mathrm{~mm} \mathrm{NH}_{4} \mathrm{HCO}_{3}$ with $0.1 \%$ SDS and $1 \mathrm{~mm}$ $\mathrm{CaCl}_{2}$, and reduced with $5 \mathrm{~mm}$ dithiothreitol (DTT, Bioshop Canada Inc., Burlingron, ON, Canada) for $60 \mathrm{~min}$ at $60^{\circ} \mathrm{C}$. After cooling to room temperature, the reduced protein was alkylated with $10 \mathrm{~mm}$ iodoacetamide (Sigma) for $20 \mathrm{~min}$ in the dark. The Sequencing Grade Modified Trypsin (Promega, Madison, WI, USA) was added at a 1:50 trypsin:target protein ratio and incubated for $3 \mathrm{~h}$ at $37^{\circ} \mathrm{C}$. After that time, the ratio of enzyme:substrate was increased to $1: 25$. The sample $(32 \mu \mathrm{l})$ was incubated overnight at $30^{\circ} \mathrm{C}$ and then the reaction was stopped by addition of $3 \mu \mathrm{l}$ of $1 \mathrm{M} \mathrm{HCl}$. The resulting peptide mixture (100 $\mu \mathrm{l}$ of fourfold diluted sample) was separated by HPLC on a Eurosil Bioselect 300-5 C-18 column (Knauer, Berlin, Germany) at a flow rate of $1 \mathrm{ml} /$ min with a spectrophotometric detection at $215 \mathrm{~nm}$. Chromatography was performed in a two solvent system [solvent A: $0.1 \%$ trifluoroacetic acid (TFA, spectrometric grade, Sigma) in HPLC grade water; solvent B: $0.08 \%$ TFA in $80 \%$ acetonitrile (HPLC gradient grade, Merck, Darmstadt, Germany)], with a linear gradient from 1 to $55 \%$ of B in 90 min. Collected peptides were evaporated, resuspended in $30 \%$ methanol (Merck) with $0.1 \% \mathrm{HCOOH}$ (Sigma) and analyzed by HCT Ultra ion-trap mass spectrometer (Bruker, Bremen, Germany), equipped with an ESI ion source. Raw MS/MS data were processed automatically and Mascot compatible files (*.mgf) were created using DataAnalysis ${ }^{\mathrm{TM}}$ 4.0 software (Bruker). Tandem MS data were submitted to an in-house server with a version 2.3.0 Mascot software (Matrix Science, London, UK) (Perkins et al., 1999), for a search against the Swiss-Prot database with taxonomy restricted to fungi. The following search parameters were applied: instrument type - ESI-TRAP; enzyme specificity trypsin; $1+, 2+$ and $3+$ ions; peptide mass tollerance $- \pm 0.5 \mathrm{Da}$; MS/MS fragment ion mass tolerance $- \pm 0.3 \mathrm{Da}$; permitted number of missed cleavage $-1 ;{ }^{13} \mathrm{C}=1$. From this analysis, the purified protein was unequivocally identified as C. albicans SAP2, with 53.5\% sequence coverage and Mascot score equal to 432.

\section{Electrophoretic analysis of kininogen degradation by SAP2}

HK (Enzyme Research Laboratories, South Bend, IN, USA) and LK (Sigma) (1 and $1.5 \mu \mathrm{M}$, respectively) were incubated with SAP2 
(100:1 molar ratio) at $37^{\circ} \mathrm{C}$ for variable time (from $15 \mathrm{~min}$ to $5 \mathrm{~h}$ ) in $50 \mathrm{~mm}$ citrate buffer $\mathrm{pH} 3.5$ and the reaction was stopped by $10 \mu \mathrm{M}$ pepstatin A. Digests from $1 \mu \mathrm{g}$ kininogen were separated by SDSPAGE in the Laemmli system, using reducing sample buffer and a $12 \%$ gel, and detected by silver staining.

\section{HPLC analysis of the SAP2-catalyzed fragmentation of HK, LK and HK358-383 peptide}

HK (1 $\mu \mathrm{M})$, LK $(1.5 \mu \mathrm{M})$ and the synthetic HK358-383 peptide with the sequence ISLMKRPPGFSPFRSSRIGEIKEETT matching that of the kinin-containing domain D4 of human kininogens $(10 \mu \mathrm{M}$, LipoPharm.pl, Zblewo, Poland) were cleaved by SAP2 (at 25:1, 50:1 or 100:1 molar ratio) in $50 \mathrm{~mm}$ citrate buffer $\mathrm{pH} 3.5$ at $37^{\circ} \mathrm{C}$ for $5 \mathrm{~h}$ (kininogens) or for variable time from $15 \mathrm{~min}$ to $5 \mathrm{~h}$ (HK358-383) and the reaction mixtures $(100 \mu \mathrm{l})$ were mixed with $20 \mu \mathrm{l} 1 \mathrm{M} \mathrm{HCl}$ to stop the reactions. The peptide mixtures obtained were separated on a Eurosil Bioselect 300-5 C-18 reversed-phase HPLC column (5 $\mu \mathrm{m}$, $4 \times 250 \mathrm{~mm}$ ) equipped with a precolumn (Knauer), at a flow rate of $1 \mathrm{ml} / \mathrm{min}$ with a spectrophotometric detection at $215 \mathrm{~nm}$. The separation was performed in a two solvent system (solvent A: $0.1 \%$ TFA, solvent B: $0.08 \%$ TFA in $80 \%$ acetonitrile) with a linear gradient from $10 \%$ to $30 \%$ B in $50 \mathrm{~min}$. Fractions containing distinct products of HK358-383 degradation or half-minute fractions from the separation of degraded kininogens were collected, evaporated to dryness and after dilution analyzed by MS and ELISA for the presence of kinins (see below).

\section{MS analysis of SAP2-catalyzed degradation of HK358-383 and kininogens}

The vacuum-dried peptide fractions were dissolved in a mixture of $30 \%$ methanol (Merck) and $0.1 \%$ formic acid (Sigma) and analyzed in a HCT Ultra mass spectrometer (Bruker), with ESI source and ion trap analyzer. Samples were injected into ESI source at a flow rate of $3 \mu \mathrm{l} / \mathrm{min}$ using a syringe pump (KD Scientific, Holliston, MA, USA). The analyses were performed in a positive ion mode in $\mathrm{m} / \mathrm{z}$ range between 100 and 1700 with a capillary voltage of $3.5 \mathrm{kV}$, nebulizer pressure $10 \mathrm{psi}$ and with drying gas flow of $5 \mathrm{l} / \mathrm{min}$ and temperature $300^{\circ} \mathrm{C}$. The mass spectra acquired were analyzed using a Bruker's Data Analysis software version 4.0.

\section{Determination of kinins by ELISA}

BK-like peptides were determined with an ELISA kit (Pennisula Laboratories-Bachem, San Carlos, CA, USA), strictly following the manufacturer's instructions. In this assay, specific for the five C-terminal amino acid residues of BK, biotinylated BK competes with kinins in the analyzed samples for the binding to the microplate-immobilized antiserum. The amount of the biotinylated tracer bound was determined using streptavidin-conjugated horseradish peroxidase $/ 3,3^{\prime}, 5,5^{\prime}$-tetramethylbenzidine (SA-HRP/TMB) system and the kinin concentration in the sample was estimated from a calibration curve prepared with $\mathrm{BK}$ in a concentration range of $0.1-5 \mathrm{~nm}$.

\section{Competitive kinin radioreceptor-assay}

Generation and culturing of HEK 293 cells with stable overexpression of B1 and B2 receptors: the method of obtaining HEK 293 cell lines with overexpressed kinin receptors (RB1 or RB2) using the FlpIn T-Rex-system from Invitrogen (Carlsbad, CA, USA) was described previously (Zubakova et al., 2008). The HEK 293 cells were cultured in DMEM medium (PAA, Pasching, Austria) with high glucose, Lglutamine and sodium pyruvate supplemented with $10 \%$ fetal bovine serum (FBS, Lonza, Switzerland) and penicillin/streptomycin (0.1 $\mathrm{mg} / \mathrm{ml}$, PAA). For the binding experiments, the cells were seeded in 96 -well plates pre-treated with $0.01 \%$ solutions of poly-L-lysine (Sigma) in phosphate-buffered saline (PBS, PAA), to full confluence.

Competitive radioreceptor assay (Nägler et al., 2010): after washing the cell-monolayer twice with cold PBS, HEK 293 cells were equilibrated with $200 \mu \mathrm{l}$ incubation buffer containing $40 \mathrm{~mm}$ PIPES, $100 \mathrm{~mm} \mathrm{NaCl}, 5 \mathrm{~mm} \mathrm{KCl}, 0.1 \%$ glucose, $0.05 \%$ BSA, $2 \mathrm{~mm} \mathrm{CaCl}_{2}$, $\mathrm{pH} 7.4$, and peptidase inhibitors [2 mm bacitracin (Sigma), $0.8 \mathrm{~mm}$ 1,10-phenantroline (Sigma) and $100 \mu \mathrm{m}$ captopril (Fluka, Buchs, Switzerland) for RB2-overexpressing cells or $0.5 \mathrm{~mm}$ bacitracin, $0.02 \mathrm{~mm}$ 1,10-phenantroline and $100 \mu \mathrm{M}$ captopril for RB1-bearing cells] for $30 \mathrm{~min}$ on ice. All further steps were also performed on ice. The buffer was removed and the cells were incubated for $90 \mathrm{~min}$ in $100 \mu \mathrm{l}$ of the same buffer solution containing additionally $\left[{ }^{3} \mathrm{H}\right]-$ BK (Perkin-Elmer, Waltham, MA, USA) for RB2-binding assay and [ $\left.{ }^{3} \mathrm{H}\right]-D A K D$ (Perkin-Elmer) for RB1-binding assay, in the concentrations of $2 \mathrm{~nm}$ and $1 \mathrm{~nm}$, respectively, and tenfold diluted peptide mixtures or fractions after HPLC separations. The calibration (displacement) plots were prepared with the solutions of BK, KD, MKD (for RB1-and RB2-binding assays), des-Arg ${ }^{9}$-BK, des-Arg ${ }^{10}$ KD (Bachem) and des-Arg ${ }^{10}$-MKD (obtained by carboxypeptidase M-catalyzed degradation of MKD, followed by HPLC purification) (for RB1-binding assay) at a concentration range of 0.01-30 nM. After incubation, the cells were washed four times with cold PBS and treated for $30 \mathrm{~min}$ with $200 \mu \mathrm{l}$ of dissociative solution, $0.2 \mathrm{M}$ acetic acid and $0.5 \mathrm{M} \mathrm{NaCl} \mathrm{pH} \mathrm{2.7,} \mathrm{as} \mathrm{described} \mathrm{previously}$ (Faussner et al., 2005). The supernatants containing dissociated $\left[{ }^{3} \mathrm{H}\right]-\mathrm{BK}$ or $\left[{ }^{3} \mathrm{H}\right]-\mathrm{DAKD}$ were transferred to scintillation vials filled with $2.5 \mathrm{ml}$ of scintillation fluid (Ultima Gold ${ }^{\mathrm{TM}}$, Parkin-Elmer) and the radioactivity was measured in a beta-counter (Wallace 1412, LKB, Uppsala, Sweden).

\section{Detection of IL- $1 \beta$ and IL- 6 secreted by U937 cell line}

U937 cell culture and stimulation: promonocytic U937 cell line (ATCC) was grown in HEPES-stabilized RPMI 1640 medium (PAA) with L-glutamine, supplemented with $10 \%$ FBS and streptomycin/ penicillin $(0.1 \mathrm{mg} / \mathrm{ml})$, to the maximal density of $10^{6} \mathrm{cells} / \mathrm{ml}$, at $37^{\circ} \mathrm{C}$ in an atmosphere containing $5 \% \mathrm{CO}_{2}$. For the cell stimulation, $4 \times 10^{6}$ of undifferentiated cells were incubated with $1 \mathrm{~nm} \mathrm{BK}, \mathrm{KD}$ or MKD, various concentrations of peptide mixtures obtained by SAP2 treatment of LK, SAP2 (as a negative control) and $0.1 \mu \mathrm{g} / \mathrm{ml}$ LPS (Sigma) from Escherichia coli (as a positive control), at $37^{\circ} \mathrm{C}$ for $24 \mathrm{~h}$ in RPMI medium supplemented with $2 \%$ FBS, protease inhibitor cocktail (Sigma Cat. No P1860) and kininase inhibitors (20 $\mu \mathrm{M}$ captopril, $500 \mu \mathrm{M}$ bacitracin and $100 \mu \mathrm{M}$ DL-2-mercaptomethyl-3guanidinoethylthiopropionic acid (MGTA, Calbiochem-Behring, La Jolla, CA) in $250 \mu$ l total volume.

ELISA assay: after incubation, the cells were centrifuged and IL- $1 \beta$ and IL- 6 concentrations were determined in the supernatants by Human IL- $1 \beta$ ELISA Set II and Human IL-6 ELISA Set (BD Biosciences, San Diego, CA, USA), following the manufacturer's instruction. Briefly, ILs from supernatants were bound to microplateimmobilized antibody and then the secondary biotinylated-antibody bound to adsorbed ILs. The amount of bound tracer was determined using the SA-HRP/TMB system. The concentrations of ILs were estimated from calibration curves prepared with IL standards at a concentration range of 3-250 pM. 


\section{Acknowledgements}

This work was supported in part by the Ministry of Science and Higher Education, Poland (grant No. N N303 572538 to A.K.). The Faculty of Biochemistry, Biophysics and Biotechnology of the Jagiellonian University is a beneficiary of structural funds from the European Union (grant No. POIG.02.01.00-12-064/08 - 'Molecular biotechnology for health').

\section{References}

Barbasz, A. and Kozik, A. (2009). The assembly and activation of kinin-forming systems on the surface of human U-937 macrophage-like cells. Biol. Chem. 390, 269-275.

Barbasz, A., Guevara-Lora, I., Rapała-Kozik, M., and Kozik, A. (2008). Kininogen binding to the surfaces of macrophages. Int. Immunopharmacol. 8, 211-216.

Blais, C.H. Jr., Marceau, F., Rouleau, J., and Adam, A. (2000). The kallikrein-kininogen-kinin system: lessons from the quantification of endogenous kinins. Peptides 21, 1903-1940.

Chaffin, W.L. (2008). Candida albicans cell wall proteins. Microbiol. Mol. Biol. Rev. 72, 495-544.

Colman, R.W. and Schmaier, A.H. (1997). Contact system: a vascular biology modulator with anticoagulant, profibrinolytic, antiadhesive and proinflammatory attributes. Blood 90, 3819-3843.

Colman, R.W., Jameson, B.A., Lin, Y., Johnson, D., and Mousa, S.A. (2000). Domain 5 of high molecular weight kininogen (kininostatin) down-regulates endothelial cell proliferation and migration and inhibits angiogenesis. Blood 95, 545-550.

dos Santos, A.L., de Carvalho, I.M., da Silva, B.A., Portela, M.B., Alviano, C.S., and de Araújo Soares, R.M. (2006). Secretion of serine peptidase by a clinical strain of Candida albicans: influence of growth conditions and cleavage of human serum proteins and extracellular matrix components. FEMS Immunol. Med. Microbiol. 46, 209-220.

Faussner, A., Bauer, A., Kalatskaya, I., Schüssler, S., Seidl, C., Pround, D., and Jochum, M. (2005). The role of helix 8 and of cytosolic $\mathrm{C}$-termini in the internalizatrion and signal transduction of $B_{1}$ and $B_{2}$ bradykinin receptors. FEBS J. 272, 129-140.

Gera, L., Roy, C., Bawolak, M.T., Bouthillier, J., Adam, A., and Marceau, F. (2011). Met-Lys-bradykinin-Ser-Ser, a peptide produced by the neutrophil from kininogen, is metabolically activated by angiotensin converting enzyme in vascular tissue. Pharmacol. Res. 64, 528-534.

Gomes, R.A., Juliano, L., Chagas, J.R., and Hial, V. (1997). Characterization of kininogenase activity of an acidic proteinase isolated from human kidney. Can. J. Physiol. Pharmacol. 75, 757-761.

Gropp, K., Schild, L., Schindler, S., Hube, B., Zipfel, P.F., and Skerka, C. (2009). The yeast Candida albicans evades human complement attack by secretion of aspartic proteases. Mol. Immunol. 47, 465-475.

Hial, V., Keiser, H.R., and Pisano, J.J. (1976). Origin and content of methionyl-lysyl-bradykinin, lysyl-bradykinin and bradykinin in human urine. Biochem. Pharmacol. 15, 2499-2503.

Imamura, T., Potempa, J., and Travis, J. (2004). Activation of the kallikrein-kinin system and release of new kinins through alternative cleavage of kininogens by microbial and human cell proteinases. Biol. Chem. 385, 989-996.

Imamura, T., Tanase, S., Szmyd, G., Kozik, A., Travis, J., and Potempa, J. (2005). Induction of vascular leakage through release of bradykinin and a novel kinin by cysteine proteinases from Staphylococcus aureus. J. Exp. Med. 201, 1669-1676.

Joseph, K. and Kaplan, A.P. (2005). Formation of bradykinin: a major contributor to the innate inflammatory response. Adv. Immunol. 86, 159-208.

Kaminishi, H., Tanaka, M., Cho, T., Maeda, H., and Hagihara, Y. (1990). Activation of the plasma kallikrein-kinin system by Candida albicans proteinase. Infect. Immun. 58, 2139-2143.

Karkowska-Kuleta, J., Rapala-Kozik, M., and Kozik, A. (2009). Fungi pathogenic to humans: molecular bases of virulence of Candida albicans, Cryptococcus neoformans, and Aspergillus fumigatus. Acta Biochim. Pol. 56, 211-224.

Karkowska-Kuleta, J., Kozik, A., and Kozik-Rapala, M. (2010). Binding and activation of the human plasma kinin-forming system on the cell walls of Candida albicans and Candida tropicalis. Biol. Chem. 391, 97-103.

Karkowska-Kuleta, J., Kedracka-Krok, S., Rapala-Kozik, M., Kamysz, W., Bielinska, S., Karafova, A., and Kozik, A. (2011). Molecular determinants of the interaction between human high molecular weight kininogen and Candida albicans cell wall: Identification of kininogen-binding proteins on fungal cell wall and mapping the cell wall-binding regions on kininogen molecule. Peptides 32, 2488-2496.

Khan, M.A., Bradford, H.N., Isordia-Salas, I., Liu, Y., Wu, Y., Espinola, R.G., Ghebrehiwet, B., and Colman, R.W. (2006). High-molecular-weight kininogen fragments stimulate the secretion of cytokines and chemokines through uPAR, Mac-1, and $\mathrm{gC} 1 \mathrm{qR}$ in monocytes. Arterioscler. Thromb. Vasc. Biol. 26, 2260-2266.

Laemmli, U.K. (1970). Cleavage of structural proteins during the assembly of the head of bacteriophage T4. Nature 227, 680-685.

Lalmanach, G., Naudin, C., Lecaille, F., and Fritz, H. (2010). Kininogens: More than cysteine protease inhibitors and kinin precursors. Biochimie 92, 1568-1579.

Leeb-Lundberg, L.M.F., Marceau, F., Müller-Esterl, W., Pettibone, D.J., and Zuraw, B. (2005). International Union Pharmacology. XLV. Classification of the kinin receptor family: from molecular mechanisms to pathophysiological consequences. Pharmacol. Rev. 57, 27-77.

Mavor, A.L., Thewes, S., and Hube, B. (2005). Systemic fungal infections caused by Candida species: epidemiology, infection process and virulence attributes. Curr. Drug Targets 6, 863-874.

Moreau, M.E., Garbacki, N., Molinaro, G., Brown, N.J., Marceau, F., and Adam, A. (2005). The kallikrein-kinin system: current and future pharmacological targets. J. Pharmacol. Sci. 99, $6-38$.

Morrow, B., Srikantha, T., and Soll, D.R. (1992). Transcription of the gene for a pepsinogen, $P E P$, is related by white-opaque switching in Candida albicans. Mol. Cell. Biol. 12, 2997-3005.

Morschhäuser, J., Virkola, R., Korhonen, T.K., and Hacker, J. (1997). Degradation of human subendothelial extracellular matrix by proteinase-secreting Candida albicans. FEMS Microbiol. Lett. 153, 349-355.

Nägler, D.K., Kraus, S., Mentele, R., Lottspeich, F., Jochum, M., and Faussner, A. (2010). A cysteine-type caroxypeptidase, cathepsin $\mathrm{X}$, generates peptide receptor agonists. Int. Immunopharmacol. 10, 134-139.

Naglik, J.R., Newport, G., White, T.C., Fernandes-Naglik, L.L., Greenspan, J.S., Greenspan, D., Sweet, S.P., Challacombe, S.J., and Agabian, N. (1999). In vivo analysis of secreted aspartyl proteinase expression in human oral candidiasis. Infect. Immun. 67, 2482-2490. 
Naglik, J.R., Challacombe, S., and Hube, B. (2003a). Candida albicans secreted aspartyl proteinases in virulence and pathogenesis. Microbiol. Mol. Biol. Rev. 67, 400-428.

Naglik, J.R., Rodgers, C.A., Shirlaw, P.J., Dobbie, J.L., FernandesNaglik, L.L., Greenspan, D., Agabian, N., and Challacombe, S.J. (2003b). Differential expression of Candida albicans secreted aspartyl proteinase and phospholipase B genes in humans correlates with active oral and vaginal infections. J. Infect. Dis. 188, 469-479.

Naglik, J.R., Moyes, D., Makwana, J., Kanzaria, P., Tsichlaki, E., Weindl, G., Tappuni, A.R., Rodgers, C.A., Woodman, A.J., Challacombe, S.J., et al. (2008). Quantitative expression of the Candida albicans secreted aspartyl proteinase gene family in human oral and vaginal candidiasis. Microbiology 154, 3266-3280.

Odds, F.C., Gow, N.A.R., and Brown, A.J.P. (2006). Toward a molecular understanding of Candida albicans virulence. In: Molecular Principles of Fungal Pathogenesis, J. Heitman, S.G. Filler, J.E. Edwards Jr. and A.P. Mitchell, eds. (Washington DC, USA: ASM Press), pp. 305-319.

Oehmcke, S. and Herwald, H. (2010). Contact system activation in severe infectious diseases. J. Mol. Med. 88, 121-126.

Perkins, D.N., Pappin, D.J., Creasy, D.M., and Cottrell, J.S. (1999). Probability-based protein identification by searching sequence databases using mass spectrometry data. Electrophoresis 18, 3551-3567.

Potempa, J. and Pike, R.N. (2009). Corruption of innate immunity by bacterial proteases. J. Innate Immun. 1, 70-87.

Rapala-Kozik, M., Karkowska, J., Jacher, A., Golda, A., Barbasz, A., Guevara-Lora, I., and Kozik, A. (2008). Kininogen adsorption to the cell surface of Candida spp. Int. Immunopharmacol. 8, 237-241.

Rapala-Kozik, M., Karkowska-Kuleta, J., Ryzanowska, A., Golda, A., Barbasz, A., Fausnerr, A., and Kozik, A. (2010). Degradation of human kininogens with the release of kinin peptides by extracellular proteinases of Candida spp. Biol. Chem. 391, 823-830.

Rapala-Kozik, M., Bras, G., Chruscicka, B., Karkowska-Kuleta, J., Sroka, A., Herwald, H., Nguyen, K.A., Eick, S., Potempa, J., and Kozik, A. (2011). Adsorption of components of the plasma kinin-forming system on the surface of Porphyromonas gingivalis involves gingipains as the major docking platforms. Infect. Immun. 79, 797-805.

Reddigari, S., Silverberg, M., and Kaplan, A.P. (1995). Assembly of the human plasma kinin-forming cascade along the surface of vascular endothelial cells. Int. Arch. Allergy Immunol. 107, 93-94.

Rodier, M.H., el Moudni, B., Kauffmann-Lacroix, C., Daniault, G., and Jacquemin, J.L. (1999). A Candida albicans metallopeptidase degrades constitutive proteins of extracellular matrix. FEMS Microbiol. Lett. 177, 205-210.

Rüchel, R. (1983). On the rennin-like activity of Candida proteinases and activation of blood coagulation in vitro. Zentralbl. Bakteriol. Mikrobiol. Hyg. A. 255, 368-379.

Sainz, I.M., Pixley, R.A., and Colman, R.W. (2007). Fifty years of research on the plasma kallikrein-kinin system: From protein structure and function to cell biology and in vivo pathophysiology. Thromb. Haemost. 98, 77-83.

Sasaguri, M., Ikeda, M., Ideishi, M., and Arakawa, K. (1988). Identification of [hydroxyproline3]-lysyl-bradykinin released from human plasma protein by kallikrein. Biochem. Biophys. Res. Commun. 150, 511-516.

Sato, F. and Nagasawa, S. (1988). Mechanism of kinin release from human low-molecular-mass-kininogen by the synergistic action of human plasma kallikrein and leukocyte elastase. Biol. Chem. Hoppe-Seyler 369, 1009-1017.

Schaller, M., Borelli, C., Korting, H.C., and Hube, B. (2005). Hydrolytic enzymes as virulence factors of Candida albicans. Mycoses 48, 365-377.

Sharma, J.N. (2006). Role of tissue kallikrein-kininogen-kinin pathways in the cardiovascular system. Arch. Med. Res. 37, 299-306.

Smith, P.K., Krohn, R.I., Hermanson, G.T., Mallia, A.K., Gartner, F.H., Provenzano, M.D., Fujimoto, E.K., Goeke, N.M., Olson, B.J., and Klenk, D.C. (1985). Measurement of protein using bicinchoninic acid. Anal. Biochem. 150, 76-85.

Smolenski, G., Sulivan, P.A., Cutfield, S.M., and Cutfield, J.F. (1997). Analysis of secreted aspartic proteinases from Candida albicans: purification and characterization of individual Sap1, Sap2 and Sap3 isoenzyme. J. Gen. Microbiol. 143, 349-356.

Taylor, B.N., Staib, P., Binder, A., Biesemeier, A., Sehnal, M., Röllinghoff, M., Morschhäuser, J., and Schröppel, K. (2005). Profile of Candida albicans-secreted aspartic proteinase elicited during vaginal infection. Infect. Immun. 73, 1828-1835.

White, T.C. and Agabian, N. (1995). Candida albicans secreted aspartyl proteinases: Isoenzyme pattern is determined by cell type, and levels are determined by environmental factors. J. Bacteriol. 177, 5215-5221.

Yang, Y.L. (2003). Virulent factors of Candida species. J. Microbiol. Immunol. Infect. 36, 223-228.

Zubakova, R., Gille, A., Faussner, A., and Hingelfeldt, U. (2008). $\mathrm{Ca}^{2+}$ signaling of kinins in cells expressing rat, mouse and human B1/B2-receptor. Int. Immunopharmacol. 8, 276-281.

Received March 18, 2012; accepted May 6, 2012 